\title{
NEW BEES OF THE GENUS COLLETES.
}

BY MYRON H. SWENK, LINCOLN, NEBRASKA.

Colletes clypeonitens, n. sp.- $q$. Length i I mm. Clypeus prominent, polished, narrowly medially sulcate, its punctures coarse but scattered and not forming striæ, its apex slightly emarginate and preceded by a transverse rim. Malar space one and one-half times as long as broad, finely striate. Antennæ black, the flagellum brownish beneath, jcint 3 decidedly longer than 4. Face dull, finely and feebly punctured, its pubescence dense and erect, dull soiled gray, becoming whitish about clypeus. Vertex shiny, minutely punctured. Cheeks dull, striate like malar space, with long white hair and short appressed pile about orbits. Prothorax without an apparent spine. Punctures of mesothorax small and widely separated, a very large polished disk subimpunctate. Scutellum finely separately punctured, these closest along posterior border. Postscutellum finely densely punctured. Pits on superior face of metathorax very irregular and poorly defined, apparently very long and narrow, medially on a broadened area. Enclosure funnel-shaped, polished, smooth, the bowl convex. Pleura shining, with fine, well separated punctures. Pubescence of thoracic dorsum dull yellowish gray, whitish on pleura, metathorax, postscutellum and below. Tegulæ yellowish testaceous. Wings clear, nervures and stigma dark brown, the former becoming yellowish at base, with the costal nervure entirely yellow. Abdomen parallel-sided, first segment shining, finely, rather indistinctly, scatteringly punctured, following segments finely, closely, indistinctly punctured. Tergum with a fine, very dense, short and appressed pile practically concealing the surface between the contrasting, very dense, shaggy fasciæ, all of a dull gray colour, basal segment with long white hairs, segments $3-6$ with white bristles, 6 bare of appressed pile. Venter shining, not banded. Legs black, with white pubescence, that on posterior femora and tibiæ very long and quite dense, carrying much pollen, outer tibial spur not pectinate, both spurs short and yellow, claws rufous, with the inner tooth submedian, front coxæ without spines.

Type.-Los Angeles, California (Dr. Davidson), i o specimen.

There is no other species known to me, except the following, which shows close relationship to this one, which is very distinct in its sparsely punctured, non-striate clypeus, long malar space and densely pilose tergum. On the whole its nearest relative is probably $C$. delodontus, Viereck, or $C$. albescens, Cresson.

February, s906. 
Colletes petalostemonis, n. sp.- $q$. Length $7-8 \mathrm{~mm}$. Very like to $C$. clypeonitens, to which it is most closely related, but differs as follows: Clypeus not sulcate nor its apex emarginate. Malar space about as long as wide. Flagellum merely fuscous below, its first joint subequal to its second. Vertex with distinct punctures of two sizes. Punctures of face distinct. Mesothorax similarly, but more coarsely punctured, those on pleura coarse and close, scutellum coarsely and sparsely punctured posteriorly. Pits on superior metathoracic face even more irregular, and the median broadening much more pronounced. Bowl of enclosure very convex, bulging. Wings white, nervures yellow, becoming dark toward the apex, the stigma large, fuscous. Abdomen similarly shaped, but much more coarsely punctured, these very distinct and quite well separated on segment $\mathrm{I}$, fine and close on 2 , indistinct on following segments. Tergum with similar appressed pile. Entire pubescence of a more silvery, less yellowish cast, tinged with the latter colour slightly on thoracic dorsum only.

f. Length $7 \mathrm{~mm}$. Clypeus concealed by long, dull white pubescence. Malar space slightly over twice as long as wide. Flagellum brown below, its first joint two-thirds as long as its second, both black, the brown joints over twice as long as wide. Abdomen very coarsely punctured, especially on segment $\mathrm{r}$, segments $\mathrm{I}-6$ with broad white apical fasciæ, the spaces between with thin pale pile not nearly concealing the surface, basal segment with long white hair, very erect, denser laterally. Otherwise essentially like the $q$.

Types.-Warbonnet Canon, Sioux County, Nebraska, July 20, I 90 I (q), July I3, Ig0 I ( f), on Petalostemon candidus. (M. Cary.)

Paratypes.-Glen, Sioux County, Nebraska, August 9, r 905 , on Petalostemon candidus, $4 q$; do. August I 4, I $q$; 40 miles north of Lusk, Wyoming, July, I895, (F. H. Snow) + , of. This species seems to be oligotropic on Petalostemon candidus, and is not common even where the plant is abundant.

Colletes solidaginis, n. sp.- $-q$. Length $9 \mathrm{~mm}$. Head very short and broad, the eyes large. Vertex scarcely depressed, minutely punctured, its sides bare, the hairs between the occeli long and erect. Clypeus somewhat shiny, uniformly slightly convex, roughened by close, coarse punctures which form irregular striæ, the apical rim prominent, intensified by a transverse depression immediately preceding it, covered with a sparse, short pale ochraceous pubescence. Front covered with a short, dense, pale ochraceous pubescence, concealing a dull, finely-roughened surface, 
that below antennæ yellowish white, the cheeks with a pale whitish pubescence and the surface slightly shiny and finely punctured. Malar space so short as to be almost wanting. Antennæ black, with the flagellum below beyond the second joint dull brownish to ferruginous, its basal joint but a shade, if any, longer than the second.

Thorax above very densely covered with a short, erect, bright fulvoochraceous pubescence, wholly concealing the surface, not at all mixed with dark hairs, longer and denser on postscutellum, paling on the sides to grayish white below. Prothoracic spines apparently wanting, mesothorax evenly punctured on a shining surface, the punctures very close and distinct, slightly sparser on a discal space, the posterior margin very finely and densely punctured. Scutellum polished and impunctate at base, elsewhere with close, coarse, rounded punctures, the postscutellum dull and finely roughened. Superior face of metathorax separated from the posterior face by an irregular rim, and divided into a series of about a dozen shining pits, which are narrow, crowded and imperfect on the sides, but quite perfect and about square medially. Posterior face with the sides shiny, weakly and scatteringly punctured, with long, pale ochraceous hairs becoming very dense laterally, the enclosure funnel-shaped, highly polished and shining, the bowl more or less ridged at the sides and base, the neck perfectly smooth, much longer than wide at base. Pleura shiny, with fine crowded punctures concealed by a dense ochraceous pubescence. Tegulæ pale testaceous. Wing short, hyaline, the nervures and stigma honey yellow. Legs slender, black, sometimes tinged with brownish on tarsi and ends of tibiæ, the pubescence short, sparse, grayish white. Front coxæ with long hairy spines. Outer tibial spurs distinctly pectinate, yellow. Claws dark, medially toothed. Abdomen with the sides subparallel, above densely covered with a very short and appressed and ochraceous pile which conceals the surface, the first segment with long dense ochraceous hairs at base and sides, its middle more sparsely pubescent and partially exposing a shining impunctate surface. The apical margins of the segments are not depressed, but have the pubescence much denser than elsewhere, forming noticeable fasciæ concolorous with the rest of the pubescence, the venter with very narrow pale fascia or fringes on the apical margins, apical segment bare, contrasting,

3. Length 6-7 mm. Resembles the $q$ except in the following points: Pubescence whitish, strongly tinged with yellowish on sides and dorsum of thorax, in general much sparser than in $q$, the clypeus covered with a 
long, dense, pale yellow pubescence, becoming whitish about base of antennæ; flagellum ferruginous beyond the first joint, which is less than half as long as second, the median ones twice as long as broad; mesothorax more finely and sparsely punctured, a large, shining, impunctate discal space with scattered punctures lateraily; legs shining black except for the ferruginous tarsi and posterior knees; abdomen slender, its first segment very polished and shiny, practically impunctate, with long pale hairs, especially basally, following segments duller, indistinctly punctured, segments I-6 with rather narrow and loose fasciæ of yellowish white pubescence continued very narrowly on venter, sparse, very short, pale hairs between, apex practically nude.

Types. - Lincoln, Nebraska, July, $q$, 0 .

This species flies at Lincoln in July and early August, visiting the flowers of Solidago Missouriensis. Its nearest ally seems to be $C$. Wilmattce, Ckll., which is an oligotropic visitor of Petalostemon, and which flies at the same time; it is readily distinguishea from that species by smaller size, dark legs, normal thoracic pubescence, etc.

Colletes ochraceus, n. sp. $-q$. Near to $C$. solidaginis, but easily distinguished from that species as follows: Larger, length I I mm. Clypeus distinctly sulcate medially, especially towards the apex, and more coarseiy punctured. Antennæ rather shorter and heavier, wholly black. Vertex with a few large punctures scattered on a minutely punctured surface. Pubescence of thoracic dorsum only slightly tinged with fulvous. Enclosure extremely small, its bowl shining but very small and irregularly roughened, the neck long and narrow. Sides of posterior face of metathorax strongly and rather closely punctured, the pubescence yellowish white. Nervures and stigma yellowish brown. Legs black, with silvery pubescence, the pectination of the hind spur very distinct, with about a dozen teeth.

Type.-Southern California (D. A. Saunders), one $q$ specimen.

Colletes rufithorax, n. sp.- $q$. Length I4-I $5 \mathrm{~mm}$. Differs from $C$. thoracicus as follows: Clypeus more coarseiy and striately punctured, especially apically, vertex with punctures of two conspicuously distinct sizes; punctures on cheeks coarse and well separated on a finely striate surface; joint 3 of antennæ $=4$; malar space slightly longer ; wings heavily clouded, nervures fusco-ferruginous; pubescence of face above clypeus strongly tinged with orange, that on thorax above brighter, more rusly red; 
outer surface of posterior tibire with black hairs among the longer pale ones; abdominal fasciæ thinner.

f. Length ro-12 mm. Distinguishable from the of thoracicus by its larger size; much heavier and broader head; longer malar space, twothirds as long as broad; shorter antennæ, falling short of metathoracic truncation, and with joint 3 one-half as long as 4 ; legs much less polished; abdomen with basal segments less regularly and more coarsely punctured, the second segment only a little more finely punctured, the fasciæ narrower, looser, more grayish.

One aberrant female from Clementon is only i $2 \mathrm{~mm}$. long, has rather clearer wings and a narrower, more polished abdomen. I do not, however, regard it as distinct.

Types. $-6 q q, 7 \delta$, all taken by Mr. H. L. Viereck in New Jersey, as follows: Ocean City, June I 9, I90I, I $q$ on wild cherry and $2 \delta \delta$ on poison ivy; Avalon, June 9 th, $3 q q$; Westville, June I 5 th, I $q$; Clementon, May 9, I899, I $\delta$, June 2, I90I, on sand myrtle, I $q$, May I4, I $90 \mathrm{I}$, on sand myrtle, I $\delta$, May I7, I90I, 2 t $\delta^{*}$; Mamuskin, May, 10 , I903, I $\delta$. I have also two $\delta$ t, taken by Rev. Birkmann at Fedor, Texas, April 19, 1902, and March 21, I904, and a for from Anglesea, N. J., May 28, 1905. (E. Daecke.) Probably a species characteristic of the Austroriparian life zone.

Colletes pulcher, n. sp. $-\delta$. Length I $4 \mathrm{~mm}$. With a general resemblance to $C$. thoracicus of, but very much larger; clypeus coarsely striatopunctate, covered with a dense beard of silky, yellowish white hair, that above clypeus dense, erect and strongly tinged with orange; vertex with sides depressed, finely, densely punctured, except on a narrow subimpunctate spot contiguous to lateral ocelli; face coarsely punctured; cheeks with coarse, close, rather indistinct punctures; malar space striate, two-thirds as long as broad; antennæ heavy, reaching well beyond tegulæ; joint 3 one-half as long as four; thorax sculptured essentially as in thoracicus; pubescence of thorax above bright rusty red, that down sides of metathorax pale orange, that on pleura, legs and below gravish-white; wings hyaline, well clouded apically, nervures reddish-brown; spurs yeliowish, the outer one finely but very distinctly pectinate; abdomen polished, elongate oval, first segment with small, distinct, well-separated punctures and sparse long grayish pubescence, denser laterally, second and third segments punctured 
much like first, but more closely and less distinctly so, following segments indistinctly punctured; apical margins of segments $\mathrm{I}-3$ siightly depressed laterally, of segments $\mathrm{I}-5$ with narrow grayish-white fasciæ, interrupted medially on $\mathrm{I}$, and continued as fringes on venter; segments $4-7$ with elongated white bristles on margins.

Type.-One of, Fedor, Texas, March I9, I904 (Birkmann). A very distinct and exceedingly handsome species.

\section{Colletes brachycerus, new name.}

Colletes brevicornis, Perez (Actes. Soc. Linn. Bordeaux, Vol. 58, p. ccxxvi, r 903), is preoccupied by a North American species, C. brevicornis, Robertson (Trans. Acad. Sci., St. Louis, Vol. VII., p. 3I5-3I6, I897). The above name is, therefore, proposed for the European species.

\section{GUESTS OF SPITTLE-INSECTS.}

Insects of the family Cercopidæ, genus Clastoptera or one close'y allied, were very common in this region last summer, and the masses of froth in which the clumsy larvæ splash their way to maturity and activity were everywhere in evidence on the twigs and leaves of the wild hazel, especially where this bush fringed the timber.

One hot July day, while annoying some of these semi-amphibious infants by poking into their unpleasant habitations, I noticed some small dipterous larvæ that were apparently enjoying life under the same conditions as the hemipter that built the foam. These flies were evidently abie to go through the life-cycle among the bubbles, for their little brown pupæ were there, glued fast to the leaves by the drying of the froth. When taken home and reared they proved to be of the species Drosophila sigmoides, Loew, mentioned in Aldrich's Catalogue of the Diptera as occurring in Texas, and collected here in Minnesota possibly for the first time.

The froth mass seemed to afford ample room for the owner and its uninvited guests, and possibly neither knew that the other was there. Even if a predatory wasp should carry off the Cercopid there would probably be enough dampness remaining to enable the flies to reach maturity among the exuviæ of the host, with the possible aid of the dew and rain to keep them moist.

C. N. Ainslie, Rochester, Minn. 


\section{$2 \mathrm{BHL}$ Biodiversity Heritage Library}

1906. "New bees of the genus Colletes." The Canadian entomologist 38, 39-44. https://doi.org/10.4039/Ent3839-2.

View This Item Online: https://www.biodiversitylibrary.org/item/22120

DOI: https://doi.org/10.4039/Ent3839-2

Permalink: https://www.biodiversitylibrary.org/partpdf/826

\section{Holding Institution}

MBLWHOI Library

\section{Sponsored by}

MBLWHOI Library

\section{Copyright \& Reuse}

Copyright Status: NOT_IN_COPYRIGHT

This document was created from content at the Biodiversity Heritage Library, the world's largest open access digital library for biodiversity literature and archives. Visit BHL at https://www.biodiversitylibrary.org. 